\title{
Does The Principle of Running a Business in Conventional Vs Sharia Become Differentiator? Study On Banking Industry in Indonesia 2009- 2014
}

\author{
Ahmad Adriansyah \\ Indonesia Banking School \\ ahmad.adriansyah@ibs.ac.id
}

Fathoni Zoebaedi

Indonesia Banking School

fathony.zoebaedi@ibs.ac.id

Ramzi A. Zuhdi

Indonesia Banking School

ramzi.zuhdi@ibs.ac.id

\begin{abstract}
Compared to conventional bank, Islamic banking industry in Indonesia is still in its early development stage. Islamic bank has different characteristic, and therefore there is a special regulation for Islamic bank. Research conducted in 22 countries (including Indonesia), shows that Islamic banking has differences with conventional banking in term of business orientation, efficiency, asset quality and stability. Another research of 13 countries (not including Indonesia), show that Islamic banking performance is lower than conventional banking (Ariss, 2010). Islamic banking in Indonesia has a unique characteristic. Most of Islamic banking in Indonesia is converted from conventional bank, owned by conventional bank or originated from a conventional bank. Some resources of Islamic bank come from conventional banking even some of them still using resource from their conventional bank as their parent. This result raises a question, whether in the context of Islamic banking in Indonesia, its performance is significantly different from conventional banks. To answer the research questions above, we do a t-test on ROA and ROE Islamic banks and conventional banks from 2009-2014. The results showed that there was no significant difference between the financial performances of Islamic banks with conventional banks, except for 2014. In 2014 Islamic bank's ROE is lower than conventional banks. This research opens the opportunity to study the factors that could cause a difference in the performance of Islamic banks vs conventional banks.
\end{abstract}

Keywords: Islamic Bank, Conventional Bank, ROA, ROE, Indonesia 
Membandingkan dengan bank konvensional, industri perbankan syariah di Indonesia relatif masih dalam tahap pengembangan awal. Bank syariah berbeda dengan bank konvensional, dan oleh karena itu ada peraturan khusus untuk bank syariah. Penelitian yang dilakukan di 22 negara (termasuk Indonesia), menunjukkan bahwa perbankan syariah memiliki perbedaan dengan perbankan konvensional dalam hal orientasi bisnis, efisiensi, kualitas aset dan stabilitas. Penelitian 13 negara (tidak termasuk Indonesia), menunjukkan bahwa kinerja perbankan syariah lebih rendah dari perbankan konvensional (Ariss, 2010). Perbankan syariah di Indonesia memiliki ciri khas yang unik. Sebagian besar perbankan syariah di Indonesia diubah dari bank konvensional, yang dimiliki oleh bank konvensional atau berasal dari bank konvensional. Beberapa sumber daya dari bank syariah berasal dari perbankan konvensional bahkan beberapa dari mereka masih menggunakan sumber daya dari bank konvensional mereka sebagai orang tua mereka. Hasil ini menimbulkan pertanyaan, apakah dalam konteks perbankan syariah di Indonesia, kinerjanya secara signifikan berbeda dari bank konvensional. Untuk menjawab pertanyaan penelitian di atas, kita melakukan uji t pada bank ROA and ROE syariah dan bank konvensional dari 2009-2014. Hasil penelitian menunjukkan bahwa tidak ada perbedaan yang signifikan antara kinerja keuangan bank syariah dengan bank konvensional, kecuali 2014. Pada tahun 2014 bank syariah ROE lebih rendah dari bank konvensional. Penelitian ini membuka kesempatan untuk mempelajari faktor-faktor yang dapat menyebabkan perbedaan dalam kinerja bank syariah vs bank konvensional.

Kata Kunci: Islamic Bank, Bank Konvensional, ROA, ROE, Indonesia

\section{Introduction}

Problem

Company must continuously seek and maintain its competitive advantage. Successful company can lose its competitive advantage and get bankrupt or acquiesced. It occurs in many industries including financial industry especially banking. History of banking industry has seen the fall down of big banks which they must join or get acquiesced with another bank. As an example, Bank Duta and Bank Universal merged into Bank Permata, four state-own bank must be combined into Bank Mandiri, etc.

Aforementioned cases are bank cases in Indonesia which conduct banking activity with conventional bank principles. During the development, in Indonesia, there is a new banking industry that is sharia banking. The establishment of Bank Muamalat as first sharia bank in $1^{\text {st }}$ May 1992 marks the beginning of this banking industry. Afterwards there was establishment of Bank Perkreditan Rakyat Syariah, such as BPRS Berkah Amal 
Sejahtera and BPRS Anda Mardhatillah (19 Agustus 1991), BPRS Amanah Rabaniah (24 Oktober 1991) and BPRS Hareukat (10 November 1991 di Aceh),

During the development, regulator assessed that sharia bank is quite different from conventional banks. Indonesian parliament issued Sharia Bank Act which is Act no. 21 2008, in addition to conventional bank regulation, Act no. 10 year 1998 which is imposed to all type of bank. One of the differences is that sharia bank is allowed to collect social funding in the form of Baitul Mal. It is funded from zakat, infaq, sodaqoh, hibah, or other social fund and it can distribute the funds to organization that manage zakat. Meanwhile, conventional bank this practice can't be conducted. It means there is already one different business feature between sharia and conventional bank.

Sharia bank in other hand has limitation compared to conventional bank. Sharia bank is not allowed to fund industry which produces haram stuffs in fiqih perception. Sharia bank is not allowed to take profit from interest although sharia bank is also having business with conventional bank which use interests.

Result of research which discusses differences between sharia bank vs conventional bank in countries with sharia bank and conventional bank shows different result. Ariss's research (2010) in 13 countries (excluding Indonesia) shows that Sharia Bank is less competitive than conventional bank. Meanwhile, Demirguc-Kunt and Merrouche (2010) stated that there are only few differences between sharia vs conventional, especially on business orientation, efficiency, asset quality, and stability. Research of Demirguc-Kunt and Merrouche (2010), was conducted in 22 countries (including Indonesia) in 2007.

Another uncommon situation in Indonesia is the close relations between sharia bank and conventional bank. Some syariah bank is conventional bank that is converted to sharia such as Bank Syariah Mandiri that was a conversion of PT Bank Susila Bakti, and recently BTPN syariah which is a conversion of Bank Sahabat Purba.

The executives of sharia bank are also from conventional bank, such as CEO of Bank Syariah Mandiri, Mr. Agus Sudiarto is previously Senior Vice President Special Asset Management in Bank Mandiri. Another example is commissioner of Bank Muamalat Indonesia, Mr. Widigdo Sukarman. He was CEO of Bank Papan Sejahtera and director of BNI. Some sharia banks are still subsidiary of conventional bank, such as UUS Bank Niaga.

Even though Indonesia has had sharia bank since 1994 (Bank Muamalat Indonesia), specific regulation on sharia bank was just issued in 2008 and university with specific program on sharia was just established in 2007/2008 in Airlangga University. Master degree on sharia banking was just established in the late 1990 or in the beginning 
of 2000 in University of Indonesia (PSTII post-bachelor program), Trisakti University, and Airlangga University Surabaya.

The discussions show that development of sharia bank and its supporting infrastructure is not moving fast even though Indonesia has huge market. This situation brings up a question on the real differences between sharia and conventional bank in terms of financial aspect especially since 2009 (Sharia Bank Act year 2008) up until now. And is there a trend of sharia bank which makes it more different from conventional bank.

\section{Problem formulation}

From the background, on the study main problem that will be studied in this research is whether there is significant difference between sharia bank and conventional one. Furthermore, this research also tries to examine, according to data in 6 years, whether there is a trend in sharia banking that makes it different from conventional bank or it's just the same.

Details issues to be answered in this study are:

1. Is ROA of sharia bank significantly different from ROA of conventional bank in 2009 ?

2. Is ROA of sharia bank significantly different from ROA of conventional bank in 2010 ?

3. Is ROA of sharia bank significantly different from ROA of conventional bank in 2011 ?

4. Is ROA of sharia bank significantly different from ROA of conventional bank in 2012 ?

5. Is ROA of sharia bank significantly different from ROA of conventional bank in 2013 ?

6. Is ROA of sharia bank significantly different from ROA of conventional bank in 2014 ?

7. Is ROE of sharia bank significantly different from ROE of conventional bank in 2009 ?

8. Is ROE of sharia bank significantly different from ROE of conventional bank in 2010 ?

9. Is ROE of sharia bank significantly different from ROE of conventional bank in 2011 ?

10. Is ROE of sharia bank significantly different from ROE of conventional bank in 2012 ?

11. Is ROE of sharia bank significantly different from ROE of conventional bank in 2013 ?

12. Is ROE of sharia bank significantly different from ROE of conventional bank in 2014 ?

\section{Scope of problem}

Based on definition of Sharia Bank in Act no 21 year 2008, sharia bank is an independent company or sharia business unit that has its main office in conventional bank. This research only focuses on sharia bank which has taken organizational form as research's limitation for sharia bank. Meanwhile conventional bank in this context is conventional bank with equal size with sharia bank. 


\section{Objectives and Benefit}

The development of sharia bank in Indonesia is very significant and its role in banking industry generally is getting more dominant. Business prospect of sharia bank is also quite good. One of its indicators is the increasing number of sharia bank which has reached 12 banks. Nevertheless, we need to admit that sharia bank is still new and small in comparison to conventional bank. Because it is still relatively new, specific research for sharia bank is still limited in number. Thus, regulator encourages research about sharia bank.

This research aims to make ground for future sharia bank vs conventional bank. If there is significant difference, future research can be directed to find dominant factors as source of competitive advantage from sharia and conventional bank. If there is no significant difference, future researcher can study the triggering factors.

\section{Literature Review}

\section{Organizational Performance}

In the strategic management perspective, sustainable competitive advantage is an endgoal that company wants to achieve (Barney, 1986; Porter, 1985). Because of that, researcher has tried to find factors that can make a company more excellent than other companies. The factors can come from outside organization (external factor) and also from within organization (internal factor). External factors are regulation from government, level of competition, company's position in front of producer and consumers, etc. Internal factor can come from situation of company's resource including human resource, financial resource, knowledge resource, etc.

Multiple sources and perspectives in seeing competitive advantage bring up definition and proxy of measurement. One of definition and the use of proxy are stated by Epetimehin, (2011). He used organization's internal factor in the form of organizational performance as competitive advantage of company.

Internal factor of organization performance can consist of many factors. One expert uses four perspectives in determining organization performance. They are learning and growth, operational, consumer, and financial perspective. It is known as balanced scorecard (Kaplan and Norton, 2001). Balanced scorecard says that company's performance is based on human resources and infrastructure (learning and growth perspective). This performance will result on consumer's satisfaction that eventually will result on company's financial performance. Without financial performance, the other three performances (consumer, operational, learning and growth) will be useless. It can be basis of the use of financial performance as proxy to represent overall organization performance. 
There are other important aspects related to organization performance. For example, whether the performance will be measured as independent construct, whether the performance will be compared to the performance of its own company last year, or whether it will be compared to other companies or performance in the same industry. For example, profit level. Performance measurement can use ongoing profit level. It can use the increase of profit in comparison to last year. It can use comparison of company's profit level to industry's average profit level. Each measurement has its positive and negative side.

In this context, measurement of organization's performance used ongoing profit level because it is more simple and applicable because this research was conducted in many banks with various characteristic and different past years.

In the context of banking, many researcher state that bank's financial performance is influenced by size of bank. Thus, bank's big factor must be controlled so the measurement of bank performance can be made and compared to other bank. Measurement of bank's profit with control over size of bank is Return on Asset (ROA) and Return on Equity (ROE). Both ratio same used as item in measuring banks performance that becomes object of this research. Besides, this research also controls research's sample that is bank in the same Bank Umum Kelompok Usaha (BUKU) category.

\section{Sharia Bank Vs Conventional Bank}

Sharia bank has similarities and differences with conventional bank. The similarity is both are entity that collect fund and re-distribute it to society. In Indonesia, it has almost the same type. In conventional bank, there is general banking so is sharia bank. If there is conventional bank in people's financing bank, there is sharia people's financing bank. Another similarity is the categorization bank according to bank's capital (BUKU).

Nevertheless, both have significant and fundamental differences. It underlies consideration on publication of Act of Sharia Bank no. 21 year 2008 where in point $C$, it is stated that "Sharia bank has specification compared to conventional bank" (Act No. 21 year 2008, 1). Thus, the definition of sharia bank is "a bank that run its business in accordance to Sharia Principles (Act no 21 years 2008, 3). Sharia principles is "Islamic law principles in banking activity according to fatwa The principle of Sharia itself as an "Islamic legal principles in banking activities by the fatwa issued by the agency that has the authority in setting the fatwa in the field of sharia" (Law No. 21 of 2008, 3).

Some uniqueness of sharia banking in Indonesia is sharia banking is not only taking form sharia banking but also sharia business unit which is under conventional bank. It means sharia business unit still has correlation with conventional bank which runs its 
business without sharia principles. Sharia Business Unit is conducted in its operational in the parent company's office.

Sharia bank's product requires not only permits from regulator but also fatwa from National Sharia Council-MUI. Products and its overall process in sharia bank must not contain riba, maisir, gharar, haram, and zalim. It means that sharia bank is not allowed to do transaction that might cause one party have a potential to get loss and produce haram products such as alcohol and gambling.

Transaction in sharia bank is based on akad which is agreed in the beginning of transaction. Akad is a written agreement between sharia bank or sharia business unit with other party which state rights and responsibility for each parties according to sharia principles (UU no 21 year 2008, 4). Akad for banking products have been regulated on above regulation (UU no 21 year 2008, 4-6), they are

1. Saving is pool of money that customer trust to sharia bank and/or sharia business unit based Akad wadiah or other Akad which is not against Syariah principles and in the form of Gyro, savings, or any other forms of equivalent.

2. Bank account is a saving according to Akad wadi'ah or fund investment according to Akad mudharabah or other akad which is not against sharia principles. The withdrawal can only be done by following agreed terms and condition. However, it can't be withdrawn using check, transform form, and/or other tool in the equivalent.

3. Deposit is an investment based on Akad mudharabah or other akad which is not against sharia principles which its withdrawal can only be done on certain period time according to Akad between customer and sharia banking/sharia business unit.

4. Gyro is a saving according to Akad wadi'ah or sharia principles which the withdrawal can be anytime by using check, bilyet giro, or other payment method, and other entry.

5. Investment is trusted fund by customer to sharia bank and/or sharia business bank based on Akad mudharabah or other akad which is not against sharia principles in the form of deposit, bank account, or other equivalent form.

6. Financing is the provision of funds or bills which is equivalent to it in the form of:

a. Profit sharing transaction in the form of mudharabah and musyarakah.

b. Leasing transaction in the form of ijarah or purchase leasing in the form ijarah muntahiya bit tamlik;

c. Selling and purchasing transaction in the form of murabaha, salam, and istishna;

d. Lending-borrowing transactions in the form of qardh;

e. Service-rent transactions in the form of ijarah for multi-service transaction based on agreements between the Sharia Bank and/or Sharia Business Unite and other party that require funded party to return repay the funds after a certain period of 
time in exchange for ujrah, without reward, or profit sharingPembiayaan adalah penyediaan anda atau tagihan yang dipersamakan dengan itu berupa:

7. Collateral is an additional security, both in moving objects and non-moving objects which is given by the owner to Sharia Bank and/or Sharia Business Unit to guarantee acquittal of obligation of customer who receives the facility.

8. Storage is a treasury according to Akad between sharia bank or sharia business unit and saver with provision that sharia bank and sharia business unit does not own the fund.

9. Wali Amanat is Sharia Bank that represents security holder based on Akad wakalah between sharia Bank and security holder.

\section{Conceptual model and hypothesis development}

Research by Ariss (2010) in 13 countries (excluding Indonesia) states that Sharia Bank is less competitive than conventional bank. In another research (Demirguc-Kunt and Merrouche, 2010), there is a very few differences between Sharia Bank and Conventional bank in terms of business orientation, efficiency, asset quality, and stability. Research by Demirguc in 13 countries (excluding Indonesia) states that Sharia Bank is less competitive than conventional bank. Research of Demirguc-Kunt and merrouche (2010) in 22 countries (including Indonesia) in 2007. There are two contradictions in two studies above. It raises question on whether activity of Sharia Bank is different from conventional bank. Besides, it is also important to study the differences in the context of banking industry in Indonesia especially after there is special regulation that oversee Sharia Bank (UU no. 21 year 2008). Thus, we draw hypothesis as follow:

H1a: There is a significant difference between ROA of Sharia Bank and ROA of Conventional Bank in 2009.

$\mathrm{H} 1 \mathrm{~b}$ : There is a significant difference between ROA of Sharia Bank and ROA of Conventional Bank in 2010.

H1c: There is a significant difference between ROA of Sharia Bank and ROA of Conventional bank in 2011.

$\mathrm{H} 1 \mathrm{~d}$ : There is a significant difference between ROA of Sharia Bank and ROA of Conventional bank 2012.

H1e: There is a significant difference between ROA of Sharia Bank and ROA of Conventional bank 2013.

H1f: There is a significant difference between ROE of Sharia Bank and ROE of Conventional bank 2014. 
H2a: There is a significant difference between ROE of Sharia Bank and ROE of Conventional bank 2009.

H2b: There is a significant difference between ROE of Sharia Bank and ROE of Conventional bank 2010.

H2c: There is a significant difference between ROE of Sharia Bank and ROE of Conventional bank 2011.

$\mathrm{H} 2 \mathrm{~d}$ : There is a significant difference between ROE of Sharia Bank and ROE of Conventional bank 2012.

H2e: There is a significant difference between ROE of Sharia Bank and ROE of Conventional bank 2013.

H2f: There is a significant difference between ROE of Sharia Bank and ROE of Conventional bank 2014.

\section{Methods}

Variable Operational Definition and Overall Research Model

ROA and ROE data of conventional bank can be accessed in Bank Indonesia official website as regulator of banking in Indonesia. ROA and ROE data is data at the end of the year (per December on particular year). Sharia Bank and Conventional Bank definition follows definition of Act No. 21 Year 2008 which the classification can be seen on the Bank Indonesia website.

Research Design

Number of sharia bank vs conventional bank follows actual number of bank on certain year. Number of sharia bank and conventional bank can change in the next year. It is because there is corporate action such as merger, acquisition, or conversion from conventional bank to sharia bank. Hypothesis 1 and 2 examinations will be conducted with $t$ test and the use of SPSS 21.

On the above, it is said that this research controls research's sample based on total of bank's capital (BUKU Bank). Because all Sharia Banks in Indonesia in 2009-2014 are in BUKU 1 and BUKU 2, conventional bank as the comparator will be bank in BUKU 1 \& BUKU 2. Sharia Bank and Conventional Bank in BUKU 1 and BUKU 2 will be sample target of this research.

\section{Research sample}

In the previous section, it is stated that this research is conducted by comparing sharia bank and conventional bank which have the same capital, in BUKU 1 (Bank with core capital less than 1 Billions) and BUKU 2 (Bank with core capital between Rp 1 Billion to 5 
Billion with core capital Rp1 Trillion to less than Rp5 Trillion). As a note, Sharia Business Unit of conventional bank can't be sample of this research. Source of data can be accessed from website of Indonesia central bank. All sharia as sample for this research are:

1. BNI Syariah (BNIS)

2. Mega Syariah (BSMI)

3. Muamalat (BMI)

4. Syariah mandiri (BSM)

5. BRI Syariah (BRIS)

6. BCA Syariah (BCAS)

7. Jabar Banten Syariah (BJBS)

8. Panin Syariah (BPS)

9. Syariah Bukopin (BSB)

10. Victoria Syariah (BVS)

11. Maybank Syariah Indonesia

Out of 68 conventional banks in BUKU 1 and BUKu 2, there are only 58 banks used in this research. The other 10 banks can't be used due to incomplete data in the website of Bank Indonesia. The 58 banks are:

1. BPD Jawa Tengah

30. Bank Victoria International

2. Bank Mayapada International

31. Prima Master Bank

3. ICBC Indonesia Bank

32. Bank Resona Perandia

4. BPD Kalimantan Timur

33. PT Bank Index Selindo

5. Ekonomi Raharja Bank

34. PT Bank Bnp Paribas Indonesia

6. Bank of DKI

35. PT Bank Sinarmas, Tbk

7. BPD Bali

36. PT Bank Artha Graha Internasional

8. BPD Kalimantan Selatan

37. PT Bank Mestika Dharma

9. BPD Sumatera Selatan \& Bangka Belitung

38. PT Bank Hana

10. Bank of Aceh

39. PT Bank Nationalnobu

11. BPD Papua

40. PT Bank Bumi Arta, Tbk

12. BPD Nusa Tenggara Timur

41. PT Bank Kalimantan Tengah

13. PT BPD Jambi

42. PT Bank Pundi Indonesia

14. PT. BPD Nusa Tenggara Barat

43. PT Bank Capital Indonesia,

15. BPD Sulawesi Utara

44. PT Bank Jasa Jakarta

16. BPD Bengkulu

45. PT. BPD Sulawesi Tengah

17. BPD Lampung

46. PT Bank Yudha Bhakti

18. BPD Maluku

47. PT Bank Maspion Indonesia 
19. The Royal Bank Of Scotland

20. Rabobank International Indonesia Bank

21. BPD Sulawesi Tenggara

22. Sahabat Sampoerna Bank

23. BPD Yogyakarta

24. Bank Of India Indonesia

25. Bank Bisnis Internasional

26. Bank Fama Internasional

27. Bank Harda Internasional

28. Woori Indonesia Bank

29. Bank Mayora
48. PT Bank SBI Indonesia

49. PT Bank Agris

50. PT Bank Kesejahteraan Ekonomi

51. PT Bank Sinar Harapan Bali

52. PT Bank Ina Peranda

53. PT Bank Metro Express

54. PT Bank Dinar Indonesia

55. PT Bank Mitraniaga

56. PT Bank Artos Indonesia

57. PT Bank Ganesha

58. PT Bank Andara

\section{Result and Discussion}

Scores of Islamic Banking and Conventional Performance 2009-2014

Financial performance that will be compared is Return on Asset (ROA) and Return on Equity (ROE). ROA and ROE data can be obtained from Bank Indonesia official website (www.bi.go.id). ROA Data can be seen in table 4.1 meanwhile ROE in table 4.2.

Table 4.1. ROA Sample Data 2009-2014

\begin{tabular}{|c|c|c|c|c|c|c|}
\hline Sharia Bank & 2014 & 2013 & 2012 & 2011 & 2010 & 2009 \\
\hline 1. Bank BNI Syariah & 1 & 1 & 1 & 1 & 0 & 0 \\
\hline Mega Syariah & 0 & 2 & 3 & 1 & 1 & 2 \\
\hline Muamalat & 0 & 0 & 1 & 1 & 1 & 0 \\
\hline Syariah Mandiri & 0 & 1 & 2 & 1 & 2 & 2 \\
\hline 5. Bank Bri Sharia & 0 & 1 & 1 & 0 & 0 & 0 \\
\hline Bank Bca Sharia & 0 & 1 & 0 & 0 & 0 & 0 \\
\hline Bank Jabar Banten Sharia & 0 & 0 & 0 & 1 & 0 & 0 \\
\hline Bank Panin Sharia & 1 & 1 & 3 & 1 & -2 & -1 \\
\hline Bank Sharia Bukopin & 2 & 7 & 0 & 0 & 0 & 0 \\
\hline 10. Bank Victoria Sharia & -1 & 0 & 1 & 6 & 1 & 0 \\
\hline 11. Bank Maybank Sharia Indonesia & 3 & 2 & 2 & 3 & 4 & 5 \\
\hline \multicolumn{7}{|l|}{ Conventional Bank } \\
\hline 1. BPD Jawa Tengah & 2 & 3 & 2 & 2 & 2 & 4 \\
\hline Bank Mayapada International & 1 & 2 & 2 & 2 & 1 & 0 \\
\hline Bank ICBC Indonesia & 1 & 1 & 1 & 0 & 0 & 0 \\
\hline BPD Kalimantan Timur & 2 & 2 & 2 & 3 & 5 & 3 \\
\hline Bank Ekonomi Raharja & 0 & 1 & 1 & 1 & 1 & 2 \\
\hline 6. Bank DKI & 2 & 1 & 1 & 2 & 1 & 2 \\
\hline BPD Bali & 3 & 3 & 4 & 3 & 3 & 4 \\
\hline 8. BPD Kalimantan Selatan & 2 & 2 & 1 & 2 & 4 & 3 \\
\hline 9. BPD Sumatera Selatan And & 2 & 1 & 1 & 6 & 2 & 2 \\
\hline 10. BANK Aceh & 3 & 3 & 3 & 2 & 1 & 3 \\
\hline 11. BPD Papua & 1 & 2 & 2 & 3 & 2 & 3 \\
\hline 12. BPD Nusa Tengqara Timur & 3 & 3 & 3 & 4 & 4 & 4 \\
\hline 13. PT BPD Jambi & 3 & 4 & 3 & 3 & 5 & 5 \\
\hline 14. PT. BPD Nusa Tenggara Barat & 4 & 5 & 5 & 5 & 6 & 4 \\
\hline 15. BPD Sulawesi Utara & 2 & 3 & 2 & 2 & 3 & 1 \\
\hline 16. BPD Bengkulu & 3 & 4 & 3 & 3 & 4 & 3 \\
\hline 17. BPD Lampung & 3 & 1 & 2 & 3 & 5 & 3 \\
\hline 18. BPD Maluku & 0 & 3 & 3 & 4 & 3 & 3 \\
\hline
\end{tabular}




\begin{tabular}{|c|c|c|c|c|c|c|}
\hline 19. The Royal Bank Of Scotland & 1 & 2 & 0 & 0 & 0 & 0 \\
\hline 20. Bank Rabobank International & 0 & 0 & 0 & 0 & 0 & 1 \\
\hline 21. BPD Sulawesi Tenggara & 4 & 4 & 5 & 7 & 6 & 5 \\
\hline 22. BANK Sahabat Sampoerna & 1 & 1 & 0 & 0 & 3 & 3 \\
\hline 23. BPD Yogyakarta & 2 & 2 & 2 & 2 & 2 & 3 \\
\hline 24. Bank Of India Indonesia & 3 & 3 & 3 & 3 & 2 & 3 \\
\hline 25. Bank Bisnis Internasional & 2 & 2 & 1 & 2 & 3 & 3 \\
\hline 26. Bank Fama Internasional & 2 & 3 & 3 & 4 & 4 & 4 \\
\hline 27. Bank Harda Internasional & 0 & 1 & 1 & 1 & 1 & 0 \\
\hline 28. Bank Woori Indonesia & 3 & 5 & 3 & 4 & 4 & 5 \\
\hline 29. Bank Mayora & 0 & 0 & 0 & 0 & 1 & 0 \\
\hline 30. Bank Victoria International & 0 & 1 & 0 & 0 & 1 & 1 \\
\hline 31. Prima Master Bank & 0 & 0 & 0 & 0 & 0 & 0 \\
\hline 32. Bank Resona Perandia & 1 & 4 & 3 & 3 & 3 & 3 \\
\hline 33. PT Bank Index Selindo & 2 & 2 & 2 & 1 & 1 & 1 \\
\hline 34. PT Bank Hana & 2 & 2 & 1 & 1 & 1 & 0 \\
\hline 35. PT Bank Sinarmas, Tbk & 1 & 1 & 1 & 1 & 1 & 0 \\
\hline 36. PT Bank Artha Graha & 0 & 1 & 0 & 0 & 0 & 0 \\
\hline 37. PT Bank Mestika Dharma & 3 & 5 & 5 & 4 & 3 & 4 \\
\hline 38. PT Bank Bnp Paribas Indonesia & 4 & 1 & 1 & 3 & 5 & 11 \\
\hline 39. PT Bank Nationalnobu & 0 & 0 & 0 & 1 & 2 & 2 \\
\hline 40. PT Bank Bumi Arta, Tbk & 1 & 2 & 2 & 2 & 1 & 2 \\
\hline 41. PT Bank Kalimantan Tengah & 4 & 3 & 3 & 3 & 3 & 2 \\
\hline 42. PT Bank Pundi Indonesia, & -1 & 1 & 0 & -4 & -12 & -7 \\
\hline 43. PT Bank Capital Indonesia, & 1 & 1 & 1 & 0 & 0 & 1 \\
\hline 44. PT Bank Jasa Jakarta & 2 & 2 & 2 & 2 & 2 & 3 \\
\hline 45. PT. BPD Sulawesi Tengah & 3 & 3 & 1 & 3 & 5 & 4 \\
\hline 46. PT Bank Yudha Bhakti & 0 & 0 & 1 & 1 & 1 & 0 \\
\hline 47. PT Bank Maspion Indonesia & 0 & 1 & 1 & 1 & 1 & 1 \\
\hline 48. PT Bank SBI Indonesia & 0 & 0 & 0 & 1 & 0 & 0 \\
\hline 49. PT Bank Agris & 0 & 0 & 0 & 2 & 1 & 2 \\
\hline 50. PT Bank Kesejahteraan Ekonomi & 0 & 2 & 2 & 2 & 2 & 2 \\
\hline 51. PT Bank Sinar Harapan Bali & 2 & 2 & 2 & 2 & 2 & 3 \\
\hline 52. PT Bank Ina Peranda & 1 & 0 & 1 & 0 & 1 & 2 \\
\hline 53. PT Bank Metro Express & 1 & 0 & 0 & 1 & 1 & 2 \\
\hline 54. PT Bank Dinar Indonesia & 0 & 1 & 1 & 2 & 1 & 2 \\
\hline 55. PT Bank Mitraniaga & 0 & 0 & 0 & 0 & 0 & 0 \\
\hline 56. PT Bank Artos Indonesia & 0 & 0 & 0 & 0 & 0 & 0 \\
\hline 57. PT Bank Ganesha & 0 & 0 & 0 & 0 & 1 & 0 \\
\hline 58. PT Bank Andara & -1 & -1 & 0 & -5 & -7 & -15 \\
\hline
\end{tabular}

From the data above, it can be seen that there is sharia and conventional bank with positive ROA (bank gains profit) and negative ROA (bank suffers loss). The biggest profit earning bank is PT Bank BNP Paribas Indonesia (conventional bank) in 2009 with total $11 \%$, meanwhile bank with the biggest loss is Bank Andara (conventional bank) in 2009 with total $-15 \%$. Bank Sharia Bukopin in 2013 becomes the highest profit earning bank with $7 \%$ total profit. Meanwhile Bank Panin Sharia suffers the biggest loss by $2 \%$ in 2010. ROE data can be seen on the table 4.2.

Tabel 4.2. ROE Data of research sample 2009-2014

\begin{tabular}{|c|c|c|c|c|c|c|}
\hline Bank Syariah & 2014 & 2013 & 2012 & 2011 & 2010 & 2009 \\
\hline 1. Bank BNI Syariah & 13 & 11 & 10 & 6 & 3 & 0 \\
\hline 2. Mega Syariah & 2 & 26 & 57 & 16 & 26 & 39 \\
\hline 3. Muamalat & 2 & 11 & 29 & 20 & 17 & 8 \\
\hline 4. Syariah Mandiri & 4 & 44 & 68 & 64 & 62 & 44 \\
\hline 5. Bank Bri Syariah & 0 & 10 & 10 & 1 & 1 & 3 \\
\hline 6. Bank Bca Syariah & 2 & 4 & 2 & 2 & 1 & 0 \\
\hline
\end{tabular}




\begin{tabular}{|c|c|c|c|c|c|c|}
\hline 7. Bank Jabar Banten Syariah & 3 & 4 & 2 & 3 & 1 & 0 \\
\hline 8. Bank Panin Syariah & 7 & 4 & 7 & 2 & -4 & -1 \\
\hline 9. Bank Syariah Bukopin & 2 & 3 & 7 & 6 & 9 & 0 \\
\hline 10. Bank Victoria Syariah & -17 & 3 & 9 & 18 & 2 & 0 \\
\hline 11. Bank Maybank Syariah Indonesia & 6 & 5 & 4 & 4 & 5 & 6 \\
\hline Bank Konvensional & & & & & & \\
\hline 1. BPD Jawa Tengah & 28 & 31 & 30 & 25 & 26 & 34 \\
\hline 2. Bank Mavapada International & 20 & 22 & 17 & 11 & 7 & 4 \\
\hline 3. Bank ICBC Indonesia & 9 & 11 & 10 & 4 & 1 & 2 \\
\hline 4. BPD Kalimantan Timur & 15 & 18 & 18 & 20 & 29 & 25 \\
\hline 5. Bank Ekonomi Raharia & 2 & 9 & 7 & 10 & 14 & 19 \\
\hline 6. Bank DKI & 2 & 3 & 28 & 31 & 28 & 31 \\
\hline 7. BPD Bali & 25 & 31 & 36 & 29 & 28 & 26 \\
\hline 8. BPD Kalimantan Selatan & 19 & 21 & 17 & 19 & 32 & 30 \\
\hline 9. BPD Sumatera Selatan \& Bangka & 15 & 11 & 16 & 25 & 25 & 24 \\
\hline 10. BANK Aceh & 22 & 23 & 23 & 18 & 11 & 29 \\
\hline 11. BPD Papua & 6 & 17 & 17 & 21 & 22 & 28 \\
\hline 12. BPD Nusa Tenggara Timur & 24 & 27 & 27 & 25 & 22 & 19 \\
\hline 13. PT BPD Jambi & 19 & 23 & 25 & 31 & 48 & 29 \\
\hline 14. PT. BPD Nusa Tenggara Barat & 30 & 31 & 36 & 36 & 40 & 26 \\
\hline 15. BPD Sulawesi Utara & 23 & 36 & 30 & 23 & 32 & 19 \\
\hline 16. BPD Bengkulu & 32 & 37 & 30 & 19 & 34 & 26 \\
\hline 17. BPD Lampung & 34 & 17 & 27 & 28 & 46 & 27 \\
\hline 18. BPD Maluku & 0 & 27 & 36 & 41 & 31 & 31 \\
\hline 19. The Royal Bank Of Scotland & 1 & 4 & 0 & 0 & -2 & -1 \\
\hline 20. Bank Rabobank International & 1 & 3 & 1 & 3 & 8 & 11 \\
\hline 21. BPD Sulawesi Tenggara & 28 & 31 & 33 & 37 & 31 & 23 \\
\hline 22. BANK Sahabat Sampoerna & 5 & 5 & 0 & 0 & 11 & 11 \\
\hline 23. BPD Yogyakarta & 22 & 25 & 22 & 21 & 19 & 21 \\
\hline 24. Bank Of India Indonesia & 23 & 22 & 16 & 15 & 11 & 13 \\
\hline 25. Bank Bisnis Internasional & 7 & 6 & 4 & 5 & 5 & 5 \\
\hline 26. Bank Fama Internasional & 9 & 10 & 10 & 15 & 14 & 14 \\
\hline 27. Bank Harda Internasional & 6 & 5 & 13 & 11 & 11 & 5 \\
\hline 28. Bank Woori Indonesia & 8 & 13 & 9 & 12 & 11 & 15 \\
\hline 29. Bank Mayora & 2 & 2 & 0 & 1 & 4 & 2 \\
\hline 30. Bank Victoria International & 7 & 16 & 0 & 0 & 18 & 8 \\
\hline 31. Prima Master Bank & 6 & 6 & 5 & 3 & 2 & 3 \\
\hline 32. Bank Resona Perandia & 9 & 27 & 18 & 18 & 17 & 14 \\
\hline 33. PT Bank Index Selindo & 12 & 21 & 24 & 12 & 12 & 12 \\
\hline 34. PT Bank Hana & 10 & 9 & 4 & 4 & 5 & 0 \\
\hline 35. PT Bank Sinarmas, Tbk & 5 & 9 & 15 & 10 & 15 & 8 \\
\hline 36. PT Bank Artha Graha Internasional & 5 & 11 & 13 & 8 & 8 & 4 \\
\hline 37. PT Bank Mestika Dharma & 12 & 17 & 18 & 15 & 13 & 16 \\
\hline 38. PT Bank Bnp Paribas Indonesia & 15 & 5 & 4 & 5 & 5 & 17 \\
\hline 39. PT Bank Nationalnobu & 1 & 1 & 1 & 1 & 1 & 2 \\
\hline 40. PT Bank Bumi Arta, Tbk & 11 & 13 & 14 & 11 & 8 & 8 \\
\hline 41. PT Bank Kalimantan Tengah & 27 & 25 & 29 & 30 & 30 & 18 \\
\hline 42. PT Bank Pundi Indonesia, & -16 & 14 & 9 & -50 & -84 & -135 \\
\hline 43. PT Bank Capital Indonesia, & 8 & 10 & 8 & 5 & 5 & 6 \\
\hline 44. PT Bank Jasa Jakarta & 9 & 12 & 13 & 13 & 14 & 13 \\
\hline 45. PT. BPD Sulawesi Tengah & 24 & 20 & 9 & 15 & 28 & 21 \\
\hline 46. PT Bank Yudha Bhakti & 5 & 3 & 9 & 10 & 17 & 7 \\
\hline 47. PT Bank Maspion Indonesia & 4 & 6 & 6 & 12 & 10 & 8 \\
\hline 48. PT Bank SBI Indonesia & 4 & 9 & 6 & 11 & 5 & 3 \\
\hline 49. PT Bank Agris & 1 & 4 & 2 & 6 & 3 & 5 \\
\hline 50. PT Bank Kesejahteraan Ekonomi & -5 & 18 & 21 & 22 & 19 & 13 \\
\hline 51. PT Bank Sinar Harapan Bali & 11 & 9 & 10 & 9 & 11 & 10 \\
\hline 52. PT Bank Ina Peranda & 5 & 5 & 11 & 1 & 5 & 13 \\
\hline 53. PT Bank Metro Express & 2 & 2 & 1 & 2 & 3 & 5 \\
\hline 54. PT Bank Dinar Indonesia & 1 & 3 & 2 & 5 & 2 & 4 \\
\hline 55. PT Bank Mitraniaga & 3 & 2 & 3 & 1 & 2 & 1 \\
\hline 56. PT Bank Artos Indonesia & 1 & 2 & 0 & 1 & -1 & 0 \\
\hline 57. PT Bank Ganesha & 1 & 7 & 5 & 5 & 13 & 5 \\
\hline 58. PT Bank Andara & -11 & -18 & -1 & -14 & -21 & -25 \\
\hline
\end{tabular}


From the data above, it can be seen that there are sharia and conventional banks with positive ROE (bank gains profit) and negative ROE (bank suffers loss). Bank with the biggest profit is PT Bank Sharia Mandiri in 2012 as big as 68\%, while Bank with the biggest loss is Bank Pundi Indonesia with $-135 \%$ losses. For conventional bank, the biggest profit earner is BPD Jambi in 2010 with $48 \%$ profit; meanwhile Sharia Bank with the biggest loss is Bank Victoria Sharia with -17\% losses in 2014.

\section{Descriptive Data of Sharia and Conventional Bank 2009-2014}

Before examination to answer research question, it is needed to do descriptive analysis as additional analysis for this research. During 2009-2014 period, there are 11 Sharia bank in BUKU 1 and BUKU 2. Because this research examines the level of bank profit, this it is needed to control the size of bank. The control used in this research is by choosing sample of conventional bank that has the same size which is bank in BUKU 1 and BUKU 2 category. Indeed, there are 58 banks meeting the criteria and the data is available in the website of Indonesia Central Bank. From all samples, descriptive examination is conducted in the form of mean and deviation standard of ROA and ROE in 2009-2014. Result of descriptive examination can be seen in table 4.3.

Table 4.3. Result of Descriptive Test

\begin{tabular}{|l|l|r|r|r|}
\hline Kineria Keuangan & \multicolumn{1}{|c|}{ Prinsip } & \multicolumn{1}{c|}{ N } & \multicolumn{1}{c|}{ Mean } & \multicolumn{1}{c|}{ Std. Deviation } \\
\hline ROA2009 & Syariah & 11 &, 7273 & 1,67874 \\
\cline { 2 - 5 } & Konvensional & 58 & 1,7586 & 3,18610 \\
\hline \multirow{2}{*}{ ROA2010 } & Syariah & 11 &, 6364 & 1,50151 \\
\cline { 2 - 5 } & Konvensional & 58 & 1,6897 & 2,74793 \\
\hline \multirow{2}{*}{ ROA2011 } & Syariah & 11 & 1,3636 & 1,74773 \\
\cline { 2 - 5 } & Konvensional & 58 & 1,7241 & 1,98055 \\
\hline \multirow{2}{*}{ ROA2013 } & Syariah & 11 & 1,2727 & 1,10371 \\
\cline { 2 - 5 } & Konvensional & 58 & 1,5345 & 1,37924 \\
\hline \multirow{2}{*}{ ROA2014 } & Syariah & 11 & 1,4545 & 1,96792 \\
\cline { 2 - 5 } & Konvensional & 58 & 1,7414 & 1,45771 \\
\hline \multirow{2}{*}{ ROE2009 } & Syariah & 11 &, 5455 & 1,12815 \\
\cline { 2 - 5 } & Konvensional & 58 & 1,3966 & 1,36291 \\
\hline \multirow{2}{*}{ ROE2010 } & Syariah & 11 & 9,0000 & 16,35848 \\
\cline { 2 - 5 } & Konvensional & 58 & 10,5517 & 22,35375 \\
\hline \multirow{2}{*}{ ROE2011 } & Svariah & 11 & 11,1818 & 18,89877 \\
\cline { 2 - 5 } & Konvensional & 58 & 13,1724 & 18,31990 \\
\hline \multirow{2}{*}{ ROE2012 } & Syariah & 11 & 12,9091 & 18,30002 \\
\cline { 2 - 5 } & Konvensional & 58 & 12,1897 & 13,93022 \\
\hline \multirow{2}{*}{ ROE2013 } & Svariah & 11 & 18,6364 & 23,01422 \\
\cline { 2 - 5 } & Konvensional & 58 & 13,7414 & 10,91524 \\
\hline \multirow{2}{*}{ ROE2014 } & Syariah & 11 & 11,3636 & 12,74577 \\
\cline { 2 - 5 } & Konvensional & 58 & 13,6034 & 10,76371 \\
\cline { 2 - 5 } & Syariah & 11 & 2,1818 & 7,29134 \\
\cline { 2 - 5 } & Konvensional & 58 & 10,4138 & 10,73286 \\
\hline
\end{tabular}

Judging from ROA mean, ROA mean of conventional bank is higher than sharia bank. The highest ROA is conventional bank in 2009 as big as $1.76 \%$. For bank itself, the highest mean is in 2013 as big as $1.45 \%$. Judging from the deviation standard, in general, 
ROA of conventional bank is more diverse than ROA of sharia bank. Except for 2013, ROA of Sharia Bank is more diverse than ROA of conventional bank. The most diverse ROA data occurs in 2012 with 1.10 standard deviation.

The slight difference happens in ROE data. In general ROE mean of conventional bank is higher than ROE of Sharia bank. However, in 2011 and 2012, ROE mean of sharia bank excelled ROE mean of conventional bank. Opposite to ROA, the highest ROE mean is Sharia Bank with $18.64 \%$ in 2012. Nevertheless, the lowest ROE mean is also in Sharia Bank with $2.18 \%$ in 2014 . From ROE perspective, sharia bank is very dynamic. It is sometimes high and low unique patterns also occur in the diversity of ROE data of sharia bank compared with conventional banks. In general ROE of Sharia bank is more diverse than ROE of conventional bank except 2009 and 2014.

This descriptive analysis gives opportunities for upcoming research. For example, why is there different pattern between ROA vs ROE of sharia and conventional bank? Or Why ROA is more diverse in conventional bank but, ROE is more diverse in Sharia bank? Test result of Sharia and Conventional 2009-2014

Different test of ROA and ROE mean of sharia and conventional bank uses t test with independent sample. The confident level is $95 \%$ by using SPSS 21 . Result of t test with SPSS can be read to determine whether there is quality of variety or not, with Levene test. If there is significant use of data "Equal variances assumed". Meanwhile, if significant use data "Equal variances not assumed." Result of Lavene test can be seen in table 4.4

Table 4.4. Result of Lavene Test

\begin{tabular}{|c|c|c|c|}
\hline \multirow{2}{*}{ Data ROA and ROE } & \multicolumn{2}{|c|}{$\begin{array}{c}\text { Levene's Test for } \\
\text { Equality of Variances }\end{array}$} & \multirow{2}{*}{ Data T test used } \\
\cline { 2 - 3 } & $\mathrm{F}$ & Sig. & \\
\hline ROA2009 &, 674 &, 414 & Equal variances assumed \\
\hline ROA2010 & 1,025 &, 315 & Equal variances assumed \\
\hline ROA2011 &, 511 &, 477 & Equal variances assumed \\
\hline ROA2012 & 1,058 &, 307 & Equal variances assumed \\
\hline ROA2013 &, 001 &, 980 & Equal variances assumed \\
\hline ROA2014 & 2,003 &, 162 & Equal variances assumed \\
\hline ROE2009 &, 005 &, 943 & Equal variances assumed \\
\hline ROE2010 &, 092 &, 763 & Equal variances assumed \\
\hline ROE2011 &, 406 &, 526 & Equal variances assumed \\
\hline ROE2012 & 12,526 &, 001 & Equal variances not assumed \\
\hline ROE2013 &, 015 &, 903 & Equal variances assumed \\
\hline ROE2014 & 5,247 &, 025 & Equal variances not assumed \\
\hline
\end{tabular}

From the above table, it can be seen that in general variance of sharia bank and conventional bank is assumed equal. There are only 2 different data that is ROE in 2012 and ROE 2014 in which equal variance can't be assumed. Hereafter, t examination is conducted towards ROA of sharia bank which is compared with ROA of conventional bank. Result of $t$ examination can be seen in table 4.5. 
Table 4.5 Result of ROA T Test

\begin{tabular}{|c|c|c|c|c|c|c|c|}
\hline \multirow{2}{*}{ Year } & \multirow{2}{*}{$\mathrm{t}$} & \multirow{2}{*}{$\mathrm{df}$} & \multirow{2}{*}{$\begin{array}{c}\text { Sig. } \\
\text { (2-tailed) }\end{array}$} & \multirow{2}{*}{$\begin{array}{c}\text { Mean } \\
\text { Difference }\end{array}$} & \multirow{2}{*}{$\begin{array}{l}\text { Std. Error } \\
\text { Difference }\end{array}$} & \multicolumn{2}{|c|}{$\begin{array}{l}95 \% \text { Confidence Interval of the } \\
\text { Difference }\end{array}$} \\
\hline & & & & & & Lower & Upper \\
\hline ROA 2009 & $-1,042$ & 67 & ,301 & $-1,03135$ & ,98969 & $-3,00678$ & ,94409 \\
\hline ROA 2010 & $-1,232$ & 67 & ,222 & $-1,05329$ & ,85508 & $-2,76004$ & ,65345 \\
\hline ROA 2011 &,- 563 & 67 &, 575 &,- 36050 & ,64048 & $-1,63891$ & 91790 \\
\hline ROA 2012 &,- 593 & 67 &, 555 &,- 26176 & ,44124 & $-1,14247$ & ,61896 \\
\hline ROA 2013 &,- 565 & 67 & ,574 &,- 28683 & ,50796 & $-1,30073$ & ,72706 \\
\hline ROA 2014 & $-1,945$ & 67 & ,056 &,- 85110 & ,43755 & $-1,72446$ & ,02226 \\
\hline
\end{tabular}

From the above table, it can be inferred that there is a significant difference between ROA of Sharia Bank and ROA of conventional bank in $=5 \%$ but, significant in $\alpha=10 \%$. Even though it is not significantly different, there is a trend that shows ROA of sharia bank is always lower than ROA of conventional bank. It raises a question; does sharia bank have lower profits than conventional bank? Or can't measurement of ROA of conventional bank directly be used in measurement of sharia bank ROA? Or is there any causes?

Further, ROE's different test between sharia bank and conventional bank which can be seen in table 4.6 .

Table 4.6. Result of ROE T Test

\begin{tabular}{|c|c|c|c|c|c|c|c|}
\hline \multirow{2}{*}{ Year } & \multirow{2}{*}{$t$} & \multirow{2}{*}{$\mathrm{df}$} & \multirow{2}{*}{$\begin{array}{l}\text { Sig. } \\
\text { (2-tailed) }\end{array}$} & \multirow{2}{*}{$\begin{array}{c}\text { Mean } \\
\text { Difference }\end{array}$} & \multirow{2}{*}{$\begin{array}{l}\text { Std. Error } \\
\text { Difference }\end{array}$} & \multicolumn{2}{|c|}{$\begin{array}{c}95 \% \text { Confidence Interval of } \\
\text { the Difference }\end{array}$} \\
\hline & & & & & & Lower & Upper \\
\hline ROE 2009 & - & 67 & ,827 & $-1,55172$ & 7,09192 & $-15,70726$ & 12,60381 \\
\hline ROE 2010 & - & 67 & ,743 & $-1,99060$ & 6,05352 & $-14,07347$ & 10,09228 \\
\hline ROE 2011 & , 149 & 67 & 882 & ,71944 & 4,82288 & $-8,90707$ & 10,34594 \\
\hline ROE2012 & 691 & 10,8 &, 504 & 4,89498 & 7,08552 & $-10,72329$ & 20,51326 \\
\hline ROE 2013 & - & 67 & ,541 & $-2,23981$ & 3,64448 & $-9,51422$ & 5,03459 \\
\hline ROE2014 & & 19,3 &, $005^{\star}$ & $-8,23197$ & 2,61135 & $-13,69120$ & $-2,77275$ \\
\hline
\end{tabular}

*) Significant at $\alpha=5 \%$

\section{Managerial Implication}

In 2014 there is a significant difference between sharia bank ROE compared to conventional banks, where sharia bank ROE is lower than conventional banks. However, although not significant, sharia bank ROE was never higher than conventional bank ROE, namely in 2011 and 2012

Data from the ROA and ROE for 2009-2014, was in the year 2012 was the best year of sharia banks compared with conventional banks. While the worst year was in 2014 . These data opens opportunities for the next research, why in 2012 the bank sharia slightly outperformed conventional banks, but in 2014, just slumped. 


\section{Conclusion}

The conclusion from empirical examination is in general, based on financial performance, there is no significant difference between sharia and conventional bank. However, this pattern was different in 2014 when sharia bank is significantly different from conventional bank, especially in ROE data. Sharia bank was indeed better than conventional bank.

Although this research limits its scope in its different test only, it is interesting to further examine factors that cause significant difference between ROE of sharia bank and conventional bank in 2014. Is it because there is world crisis that has impact on economic condition and banking in Indonesia? Or are there any other causes? The factors can become moderating variable that is interesting to further examine.

From the information, there is information that in 2012 is the best year for sharia bank compared to conventional bank especially on financial performance achievement (especially ROE). It opens opportunity to find main causes why sharia bank has the best achievement in financial performance in 2012.

It is interesting to foresee whether the trend is going to continue, in 2015, 2016, and forth and the sharia bank performance is keep getting better. Or what about 2009? Or what about 2008 or 1998 when there was world financial crisis? Or is sharia bank showing worse performance than conventional bank? Is ROA and ROE of conventional bank apple to apple? The questions are interesting to answer by future research.

\section{References}

Ariss, R., T. (2010). Competitive conditions in Islamic and conventional banking: A global perspective. Review of Financial Economics. DOI: 10.1016/j.rfe.2010.03.002

Demirguc-Kunt, A. and Merrouche, O. (2010). Islamic vs. Conventional Banking: Business Model, Efficiency and Stability.

Dewi, G. (2004). Aspek-Aspek Hukum Dalam Perbankan dan Perasuransian Syariah Di Indonesia, Kencana, Jakarta.

Undang-Undang Republik Indonesia. (2008). UU no 21 tahun 2008 Tentang Perbankan Syariah.

Undang-Undang Republik Indonesia. (1998). UU no 10 tahun 1998 Tentang Perbankan. 